\title{
Effects of salinity and temperature on in vitro cell cycle and proliferation of Perkinsus marinus from Brazil
}

\author{
FERNANDO RAMOS QUEIROGA ${ }^{1}$, LUIS FERNANDO MARQUES-SANTOS ${ }^{2}$, \\ ISAC ALMEIDA DE MEDEIROS ${ }^{3}$ and PATRÍCIA MIRELLA DA SILVA ${ }^{1}$ \\ ${ }^{1}$ Laboratório de Imunologia e Patologia de Invertebrados, Departamento de Biologia Molecular, Centro de Ciências Exatas \\ e da Natureza, Universidade Federal da Paraíba, Campus I, CEP 58051-900, Foão Pessoa, PB, Brazil \\ ${ }^{2}$ Laboratório de Biologia Celular e do Desenvolvimento, Departamento de Biologia Molecular, Centro de Ciências Exatas \\ e da Natureza, Universidade Federal da Paraíba, Campus I, CEP 58051-900, Foão Pessoa, PB, Brazil \\ ${ }^{3}$ Laboratório de Farmacologia Cardiovascular, Departamento de Ciências Farmacêuticas, Centro de Ciências da Saúde, \\ Universidade Federal da Paraíba, CEP 58051-900, Foão Pessoa, PB, Brazil
}

(Received 18 Fune 2015; revised 16 October 2015; accepted 21 October 2015; first published online 18 February 2016)

S U M MAR Y

Field and in vitro studies have shown that high salinities and temperatures promote the proliferation and dissemination of Perkinsus marinus in several environments. In Brazil, the parasite infects native oysters Crassostrea gasar and Crassostrea rhizophorae in the Northeast (NE), where the temperature is high throughout the year. Despite the high prevalence of Perkinsus spp. infection in oysters from the NE of Brazil, no mortality events were reported by oyster farmers to date. The present study evaluated the effects of salinity $(5,20$ and $35 \mathrm{psu})$ and temperature $\left(15,25\right.$ and $\left.35^{\circ} \mathrm{C}\right)$ on in vitro proliferation of P. marinus isolated from a host (C. rhizophorae) in Brazil, for a period of up to 15 days and after the return to the control conditions (22 days; recovery). Different cellular parameters (changes of cell phase's composition, cell density, viability and production of reactive oxygen species) were analysed using flow cytometry. The results indicate that the $P$. marinus isolate was sensitive to the extreme salinities and temperatures analysed. Only the highest temperature caused lasting cell damage under prolonged exposure, impairing $P$. marinus recovery, which is likely to be associated with oxidative stress. These findings will contribute to the understanding of the dynamics of perkinsiosis in tropical regions.

Key words: Perkinsus marinus, schizogony, ROS, salinity, temperature.

\section{INTRODUCTION}

Protozoa of the genus Perkinsus are facultative intracellular parasites of marine molluscs, in particular bivalves (Choi and Park, 2010; Villalba et al. 2011). This genus is widely distributed worldwide and consists of seven species. Two of them, Perkinsus marinus and Perkinsus olseni, require mandatory reporting to the World Organization for Animal Health because they cause mass mortality in oysters and clams (OIE, 2015), leading to important economic losses. Therefore, there is increasing interest in conducting a variety of studies, among them those aimed at determining the environmental conditions that favour the proliferation of the parasite in the host and that can lead to death (Burreson and Ragone Calvo, 1996; Oliver et al. 1998; Cáceres-Martínez et al. 2012).

The development of Perkinsus spp. in vitro isolation and propagation techniques (Gauthier and Vasta, 1993; La Peyre et al. 1993; Mclaughlin and

* Corresponding author: Laboratório de Imunologia e Patologia de Invertebrados, Departamento de Biologia Molecular, Centro de Ciências Exatas e da Natureza, Universidade Federal da Paraíba - Campus I, 58051900, João Pessoa, PB, Brazil. Tel: +55 83 32167643. Fax: +5583 32167787. E-mail: queiroga_fr@hotmail.com
Faisal, 1998; Casas et al. 2002, 2008) enabled the performance of more specific studies addressing morphological, biochemical, physiological and genetic aspects of these protozoan parasites (Sunila et al. 2001; Chu et al. 2002; La Peyre et al. 2006; Lund et al. 2007; Ascenso et al. 2009). Perkinsus spp. cells are generally present at the trophozoite phase when cultured in vitro. Throughout their development, under controlled conditions, trophozoites increase in size and subsequently undergo schizogony, which is characterized by successive internal cell divisions, with the formation of smaller cells that will generate new trophozoites (La Peyre et al. 1993; Sunila et al. 2001; Casas et al. 2008). Some isolates present zoosporulation under these conditions; however, this event is often restricted to a small percentage of the cell population (Dungan et al. 2007; da Silva et al. 2013).

The data collected so far in field studies (Burreson and Ragone Calvo, 1996; Oliver et al. 1998; GullianKlanian et al. 2008) and in in vitro assays (Burreson et al. 1994; La Peyre et al. 2006, 2010) lead to a consensus that high temperatures and salinities favour $P$. marinus proliferation, survival and infectivity. The simultaneous occurrence of these conditions may further contribute to the negative effects of the infection and can lead to the host's death, as

Parasitology (2016), 143, 475-487. C Cambridge University Press 2016. This is an Open Access article, distributed under the terms of the Creative Commons Attribution licence (http://creativecommons.org/licenses/by/4.0/), which permits unrestricted re-use, distribution, and reproduction in any medium, provided the original work is properly cited. 
traditionally observed for its typical host, the American oyster Crassostrea virginica (Smolowitz, 2013).

From the physiological point of view, little is known about the influence of temperature and salinity on Perkinsus spp. cells. In addition to cell proliferation and viability, other in vitro cellular parameters evaluated under these environmental conditions include metabolic activity (La Peyre et al. 2006), fatty acid synthesis (Lund et al. 2004), metabolism of lipids and lipase activity (Chu et al. 2003). In cells of some aquatic organisms and yeast (Lushchak, 2011; Zhang et al. 2015), including immune defence cells of bivalves (haemocytes, Hégaret et al. 2003; Chen et al. 2007), changes in temperature and salinity may alter the production of reactive oxygen species (ROS). Although these reactive molecules may be harmful to the cell itself at high concentrations, in some types of cells, they may act as secondary messengers in important physiological processes, such as cell differentiation and proliferation (see review by Sauer et al. 2001).

In Brazil, to date, $P$. marinus has only been reported in the Northeast (NE) region. The first case of $P$. marinus was reported in oysters of the species Crassostrea rhizophorae in the estuary of the Paraíba do Norte River (State of Paraíba; da Silva et al. 2013). Subsequently, this protozoan was detected infecting Crassostrea gasar oysters in the estuaries of the São Francisco River (State of Sergipe, da Silva et al. 2014) and the Mamanguape River (State of Paraíba, Queiroga et al. 2015). In these last two reports, P. olseni and Perkinsus beihaiensis species were also identified. In all of these studies, the prevalence of Perkinsus spp. was always high, reaching $100 \%$ in some cases.

Considering that high temperatures favour $P$. marinus infection and cause pathological consequences among $C$. virginica oysters and that in the Brazilian NE region high temperatures (mean maximum air temperature in Paraíba coast is $35^{\circ} \mathrm{C}$ ) predominate throughout the year, similar negative impacts might be expected among infected oysters in that region. However, in the NE of Brazil no mortality events were reported by oyster farmers or in the literature that could be associated with perkinsiosis. It is known though that when C. gasar oysters are infected by Perkinsus spp., the immune defence competence is reduced (i.e. numbers of haemocytes and proportions of their subtypes, phagocytic capacity and ROS production; Queiroga et al. 2013), which would contribute to the weakness of oysters making them more susceptible to opportunistic or pre-existing infections.

In the light of the above information, the present study aimed to evaluate the effects of salinity and temperature on the in vitro proliferation of $P$. marinus isolated from $C$. rhizophorae oysters in Brazil. For the first time, we analysed P. marinus cell viability and proliferation using parameters obtained by flow cytometry: cell density and morphology. It was possible to identify and to quantify the modifications of cell types that occurred under the effects of physical conditions. Moreover, ROS production was measured for the first time in Perkinsus sp. cells. Our results will help us in understanding the $P$. marinus infection dynamics (prevalence and intensity of infection) on the natural environment and the impact on potential hosts on the Brazilian coast.

\section{MATERIALS AND METHODS}

\section{Perkinsus marinus isolate}

The polyclonal isolate of $P$. marinus (CR-PB192) was obtained from one $C$. rhizophorae oyster sampled from the rhizophores of the red mangrove tree (Rhizophora mangle) from the estuary of the Paraíba do Norte River (06 $58^{\prime} 16 \cdot 6^{\prime \prime} \mathrm{S}$ and $34^{\circ} 51^{\prime}$ $\left.45 \cdot 1^{\prime \prime} \mathrm{W}\right)$, State of Paraíba, NE Brazil. This region has an annual average of $1800 \mathrm{~mm}$ rainfall and $26^{\circ} \mathrm{C}$ of air temperature. At this estuary, seawater salinity and temperature range between 5-40 psu and $27-32{ }^{\circ} \mathrm{C}$, respectively (Queiroga et al. 2012).

$P$. marinus trophozoites were isolated from infected gill fragments according to the protocol adapted from Casas et al. (2002). The isolate was established on 5th May 2014 and maintained in Dulbecco's modified Eagle's medium/Nutrient Mixture F-12 Ham (Sigma, Saint Louis, Missouri, USA; DME-HAM/F12, Gauthier and Vasta, $1995)$ at $20 \mathrm{psu}$ and $25^{\circ} \mathrm{C}$. The isolate was identified as P. marinus by PCR (ribosomal RNA gene complexes, Casas et al. 2002) and the sequence obtained was submitted to GenBank (accession number KT692955).

\section{Effects of salinity and temperature on $\mathrm{P}$. marinus in vitro proliferation}

Two assays were performed independently to evaluate the effect of salinity and temperature on $P$. marinus in vitro proliferation. Prior to the assays, parasite cell suspension was held for 5 days of culture, and then rinsed by centrifugation $(377 \mathrm{~g}$ for $10 \mathrm{~min})$ and resuspended $\left(10^{6}\right.$ cells $\left.\mathrm{mL}^{-1}\right)$ in DME-HAM/F12 medium.

Salinity effects were assessed by propagating the isolate in three different media prepared at salinities: 5,20 (control) and 35 psu. For each of the salinities, the cell suspensions were distributed (4 replicates) into 24-well plates and kept at $25^{\circ} \mathrm{C}$. Temperature effects were assessed by propagating the isolate in the medium at $20 \mathrm{psu}$. Similarly, cell suspensions were distributed (4 replicates) into three 24-well plates, which were maintained at different temperatures: 15,25 (control) and $35^{\circ} \mathrm{C}$. These values of 
temperature and salinities were chosen in order to provide future comparison with the data of the natural environment of oysters.

Perkinsus marinus cell analyses were performed at different times: after $24 \mathrm{~h}, 48 \mathrm{~h}, 7$ days and 15 days. In addition, an assay was conducted (recovery assay) to evaluate the proliferation capacity of $P$. marinus upon return to control conditions of salinity (20 psu) and temperature $\left(25^{\circ} \mathrm{C}\right)$. For this purpose, a sample of the cell suspension, from each replicate and treatment (all salinity and temperature conditions), from the 15 th day of the experiment was used. The suspension was centrifuged (377 $\mathrm{g}$ for $10 \mathrm{~min})$ and resuspended (1:3) in DME-HAM/F12 medium at $20 \mathrm{psu}$ (the cell concentrations were not adjusted) and kept at $25^{\circ} \mathrm{C}$ for more 7 days (total of 22 days).

Two samples were taken from each well (4 replicates and 6 treatments $=24$ samples) at each time $(24 \mathrm{~h}$ and $48 \mathrm{~h}, 7 \mathrm{th}, 15 \mathrm{th}$ and $22 \mathrm{nd}$ day $=120$ samples) to perform analyses on flow cytometry and light microscopy.

\section{Flow cytometry analysis}

The cell suspensions $(4$ replicates $/$ treatment $/$ time $=$ 120 samples) were transferred to cytometry tubes and diluted in filtered sterile seawater with the same salinity used in the assays (1:1 until $48 \mathrm{~h}$ and $1: 2$ from the 7 th day). The following parameters were analysed: cell morphology, density, viability and ROS production. Controls of unstained cells and dead cells (for viability assay) were used to adjust flow cytometer settings. The analyses were performed using a FACSCanto II flow cytometer (BD Biosciences, San Jose, California, USA). The samples were subjected to $30 \mathrm{~s}$ readings (cell density and viability) or 10000 events (ROS production). The data obtained were analysed using Flowing software (Version 2.5·1), and the cytogram images were obtained using FlowJo software (Version $\mathrm{X}$ ).

Cell morphology and density. Cell morphology was obtained from the cytograms with the FSC (Forward Scatter) and SSC (Side Scatter) detectors, which indicate cell size and internal cellular granularity, respectively. FSC vs SSC cytograms were also used to estimate the total number of $P$. marinus cells; considering the sample dilution (Hégaret et al. 2003). The proportion (\%) of each $P$. marinus cell population was estimated.

Cell viability. Cell death was evaluated with the fluorophore propidium iodide (Sigma, Saint Louis, Missouri, USA; final concentration of $10 \mu \mathrm{g}$ $\mathrm{mL}^{-1}$ ), a double-stranded DNA intercalator incapable of crossing the plasma membranes of live cells. Unstained cells were also analysed. The percentage of cells with no fluorescence in the PE detector (564-606 nm) was determined to express cell viability (Soudant et al. 2005).

Production of ROS. The fluorophore 2'7'-dichlorofluorescein diacetate (DCFH-DA, Sigma Saint Louis, Missouri, USA; final concentration of 10 $\mu \mathrm{M})$ was used for ROS analysis. The hydrophobic molecule enters the cell and is subsequently cleaved by intracellular esterases. The oxidation caused by intracellular ROS converts DCFH into DCF, which emits fluorescence (Hégaret et al. 2003; Lambert et al. 2003). Reactive nitrogen species (RNS) may also oxidize DCFH (Wardman, 2007). Fluorescence was determined using the FITC detector (515-545 nm). Unstained cells were also analysed. ROS production was calculated by subtracting the geometric fluorescence mean of the labelled cells from the non-labelled cells.

\section{Light microscopy analysis}

Considering that different cell phases (trophozoites, schizonts and zoospores) of Perkinsus spp. develop on in vitro culture (Sunila et al. 2001; Casas et al. 2002; Dang et al. 2015), light microscopy was used to correlate cell populations observed by this technique with those detected by flow cytometry.

The cell suspensions (4 replicates/treatment/time $=120$ samples) were fixed in formaldehyde (final concentration of $2 \%$ ) and used to identify and characterize (cell diameter and morphological description) each cell phase under a light microscope (Olympus BX45). Images of $P$. marinus cell cycle phases were taken with an Olympus Q-Color 5 digital camera.

\section{Statistical analysis}

Two-way factor (i.e. temperature or salinity and time) analysis of variance (ANOVA) was used for all parameters (cell viability, cell density and ROS production), followed by the Bonferroni post hoc test. Significant difference was set at $P<0 \cdot 01$. All data are reported as mean \pm s.E. Data analysis was performed using GraphPad Prism 5.0 software (San Diego, California, USA).

\section{RESULTS}

\section{Perkinsus marinus phases in vitro}

By light microscopy, throughout the salinity and temperature assays, two cell types were observed (trophozoites and schizonts; Fig. 1A-D). Trophozoites (Fig. 1A and B) had diameters ranging from $5 \cdot 3$ to $32 \cdot 1 \mu \mathrm{m}(11 \cdot 8 \pm 0 \cdot 2 \mu \mathrm{m})$ and were characterized by the presence of a prominent droplet inside the major cytoplasmic vacuole, which contained 


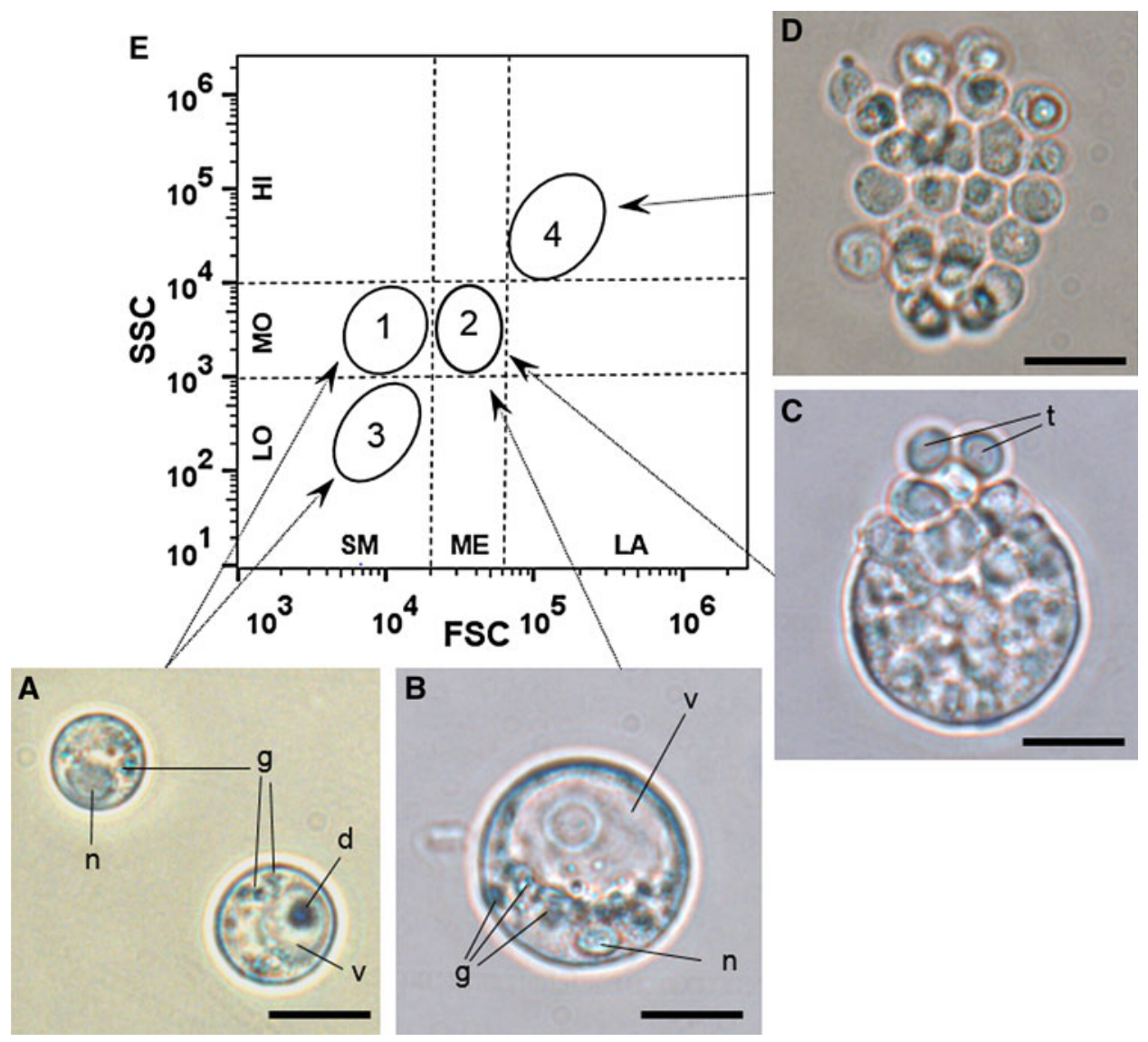

Fig. 1. Perkinsus marinus cell types observed in in vitro cultures by light microscopy (pictures A - D) and depicted in flow citometry scatter plot (graphic E). (A) Small trophozoites. Note the peripheral nuclei (n), the large vacuole (v) containing a droplet (d) and the granules in the cytoplasm (g). (B) Large trophozoite. (C) Schizont releasing small trophozoites (t). (D) Cluster of sibling trophozoites. All micrograph bars $=10 \mu \mathrm{m}$. (E) Representative flow cytometry scatter plot of $P$. marinus cell populations. Dashed lines show the limits of considered intervals for small, medium and large (SM, ME and LA, respectively) cell size (FSC - log scale) and low, moderate and high (LO, MO and HI, respectively) granularity (SSC log scale). Circles show the positions of Populations 1-4. Arrows indicate possible associations between the cell types observed by light microscopy and populations detected by flow citometry.

few granules. Schizonts had diameters ranging from $11 \cdot 3$ to $36 \cdot 9 \mu \mathrm{m}(20 \cdot 3 \pm 0 \cdot 3 \mu \mathrm{m})$ and were round or oval cells with opaque cytoplasm. Schizonts releasing small trophozoites were observed (Fig. 1C). Moreover, small trophozoite aggregates (i.e. clusters of sibling trophozoites) were observed, with the main axes ranging from $19 \cdot 2$ to $66 \cdot 1 \mu \mathrm{m}(37 \cdot 9 \pm$ $0 \cdot 8 \mu \mathrm{m})$ (Fig. 1D).

Flow cytometry morphological analyses (cell size vs granularity) indicated the presence of several cell populations, which are depicted in Fig. 1E and were numbered by the order they appeared in the cytograms. Population 1 consisted of small-sized and moderate-granularity cells; Population 2 consisted of medium-sized and moderate-granularity cells; Population 3 consisted of small-sized and low-granularity cells; and Population 4 consisted of large-sized and high-granularity cells.

Comparison of morphological characteristics of cell populations obtained with both methods (Fig. 1), indicates that: Populations 1 and 3 would correspond to small trophozoites (Fig. 1A) with higher and lower internal granularities (respectively), Population 2 would correspond to the large trophozoites (Fig. 1B) and schizonts (Fig. 1C), and Population 4 would correspond to clusters of sibling trophozoites (Fig. 1D).

Effect of salinity on in vitro P. marinus proliferation at $25^{\circ} \mathrm{C}$

Observation of cells under a light microscope showed the same patterns of occurrence of cell types at all salinities; trophozoites were observed at all-time points; however, the schizonts and clusters of sibling trophozoites appeared from the 7 th and 15 th day, respectively.

The flow cytometry analysis indicated changes in the presence and proportions of the $P$. marinus cell populations over time as shown in Fig. 2 and Table 1. However, at the lowest salinity ( $5 \mathrm{psu}$ ), the changes were distinct from those occurring at higher salinities (20 and $35 \mathrm{psu}$ ). Until $48 \mathrm{~h}$, at 20 and $35 \mathrm{psu}, P$. marinus presented exclusively as 


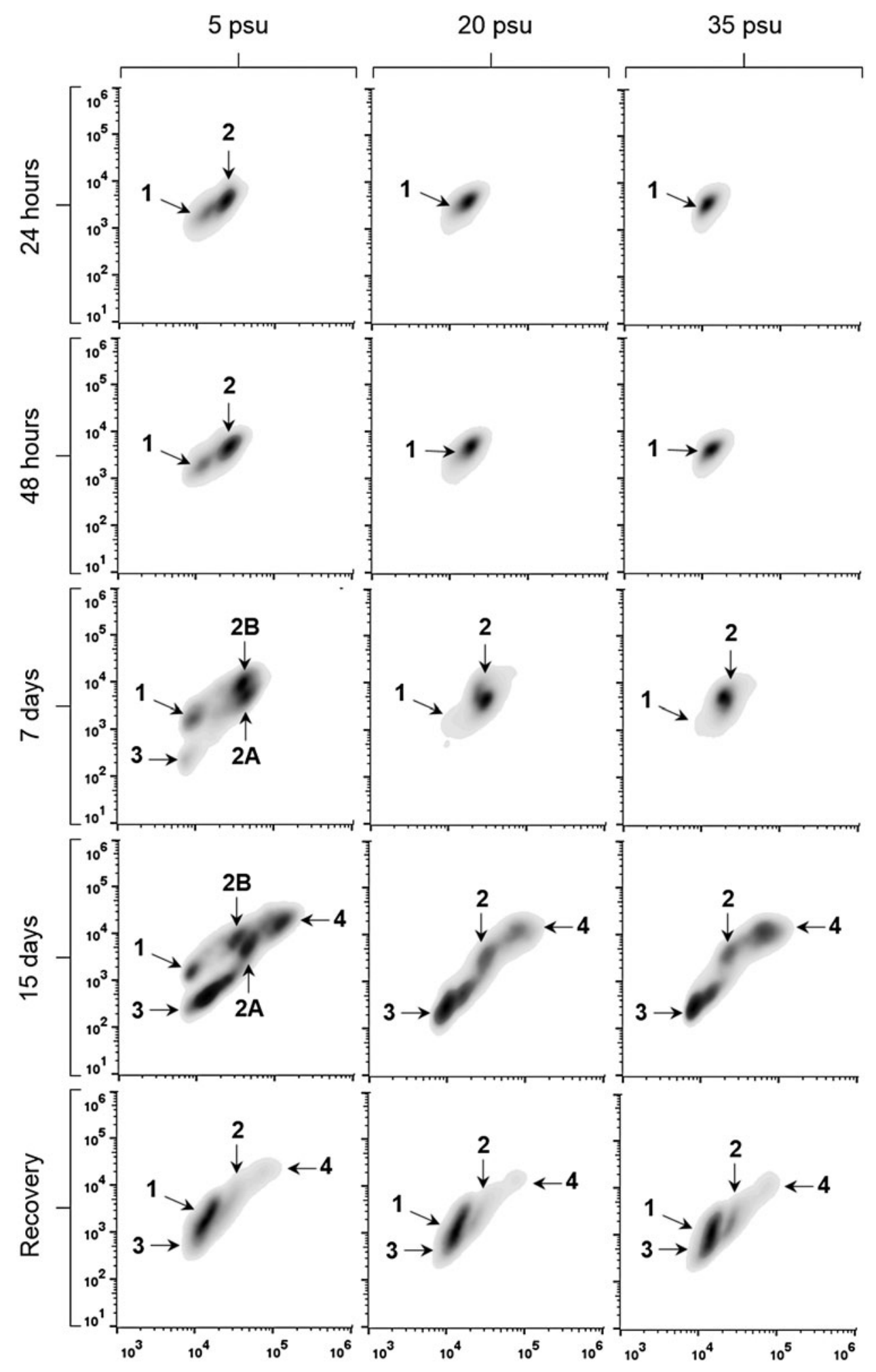

Fig. 2. Density plot of Perkinsus marinus cells maintained at 5, 20 and 35 psu (columns) at different times (24, 48 h, 7 days, 15 days and in the recovery; rows). The $x$-axis indicates cell size (FSC), and the $y$-axis indicate cell granularity (SSC), both in $\log$ scale. Ten thousand events are represented at each cytogram. Numbers (1, 2, 2A, 2B, 3 and 4) indicate different cell populations.

Population 1, whereas at $5 \mathrm{psu}$, Population 2 emerged, corresponding to $70 \cdot 5 \%(24 \mathrm{~h})$ and $74 \cdot 6 \%$ (48 h). Only on the 7 th day, at 20 and $35 \mathrm{psu}$, did Population 2 appear, $98 \cdot 3$ and $86 \cdot 2 \%$, respectively. In contrast, at $5 \mathrm{psu}$, Population 2 subdivided into two distinct populations, $2 A(42 \cdot 2 \%)$ and $2 B$ (39.1\%); and Population 3 also emerged (3\%). On the 15 th day, increased morphological variability was observed in all treatments, with all showing the simultaneous presence of the Populations 2-4. 
However, Populations $1,2 A$ and $2 B$ were sustained only at 5 psu $(8 \cdot 7,11 \cdot 8$ and $21 \cdot 6 \%$, respectively). During the recovery period at 20 psu, cell morphology homogeneity was observed for all treatments; with Populations 1-4.

Cell density, viability and ROS production of $P$. marinus cultured under different salinities are shown in Fig. 3. There was no cell proliferation at any salinity tested until the 7 th day (Fig. 3A). On the 15 th day, cell density at 20 psu was significantly higher $(P<0 \cdot 001)\left(3 \cdot 7 \pm 0 \cdot 10 \times 10^{6}\right.$ cells $\left.\mathrm{mL}^{-1}\right)$ than at $5 \mathrm{psu}\left(2 \cdot 1 \pm 0 \cdot 20 \times 10^{6}\right.$ cells $\left.\mathrm{mL}^{-1}\right)$ and at $35 \mathrm{psu}$ $\left(2 \cdot 5 \pm 0 \cdot 10 \times 10^{6}\right.$ cells $\left.\mathrm{mL}^{-1}\right)$. However, in the recovery assay, the cell density previously at $35 \mathrm{psu}$ $\left(7 \cdot 2 \pm 0 \cdot 04 \times 10^{6}\right.$ cells $\left.\mathrm{mL}^{-1}\right)$ was the same as that observed at $20 \mathrm{psu}\left(7 \cdot 3 \pm 0 \cdot 20 \times 10^{6}\right.$ cells $\left.\mathrm{mL}^{-1}\right)$ but was higher than that observed at the lowest salinity $\left(4 \cdot 4 \pm 0 \cdot 20 \times 10^{6}\right.$ cells $\left.\mathrm{mL}^{-1} ; P<0 \cdot 001\right)$.

Perkinsus marinus cell viability at control salinity (20 psu) was maintained between 81.5 and $98.7 \%$ $(91 \cdot 3 \pm 1 \cdot 40 \%$, Fig. 3B) throughout the study. For the other treatments, up to $48 \mathrm{~h}$, only cells at the highest salinity ( $35 \mathrm{psu}$ ) presented reduced viability $(79 \cdot 2 \pm 0 \cdot 40 \%, P<0 \cdot 001)$. However, the cells maintained at 5 psu experienced slightly reduced viability on the 7 th day $(84 \cdot 5 \pm 2 \cdot 20 \%, P<0 \cdot 001)$ and drastically reduced viability on the 15 th day $(31 \cdot 3 \pm 4 \cdot 00 \%$, $P<0 \cdot 001)$. Curiously, the dead cells detected on the 7 th day belonged mostly to Population $2 B(83 \cdot 2 \%)$, but not on the 15 th day $(28 \cdot 8 \%)$. In all other cases, dead cells were evenly distributed in all populations. The cell viability at $35 \mathrm{psu}(95 \cdot 1 \pm 1 \cdot 50 \%)$ on the 7 th and 15 th day was equivalent to that of treatment at 20 psu. Recovery at 20 psu enabled cells previously at 5 psu to reach high viabilities $(98 \cdot 8 \pm 0 \cdot 10 \%)$ and values statistically equal to those of the other treatments.

ROS production (Fig. 3C) was higher for cells maintained at 5 and 35 psu only at $24 \mathrm{~h}(P<0 \cdot 01)$.

\section{Effects of temperature on $\mathrm{P}$. marinus proliferation at 20 psu}

By light microscopy, it was observed that cell culture kept at extreme temperatures analysed (15 and $35^{\circ} \mathrm{C}$ ) only showed trophozoites phase until the 15 th day, but those kept at $25^{\circ} \mathrm{C}$ also had schizonts and clusters of sibling trophozoites from the 7 th day. However, recovery at $25^{\circ} \mathrm{C}$ enabled the occurrence of all cell types for each tested temperature.

Flow cytometry morphological analysis revealed changes in the presence and proportion of the P. marinus cell populations over time (Fig. 4 and Table 2). Notably, these modifications occurred slowly at extreme temperatures $\left(15\right.$ and $\left.35^{\circ} \mathrm{C}\right)$. Up until 48 h, $P$. marinus cells presented exclusively as Population 1 at all temperatures. On the 7 th day, the cells maintained at low temperature $\left(15^{\circ} \mathrm{C}\right)$ sustained Population 1, whereas those kept at the 

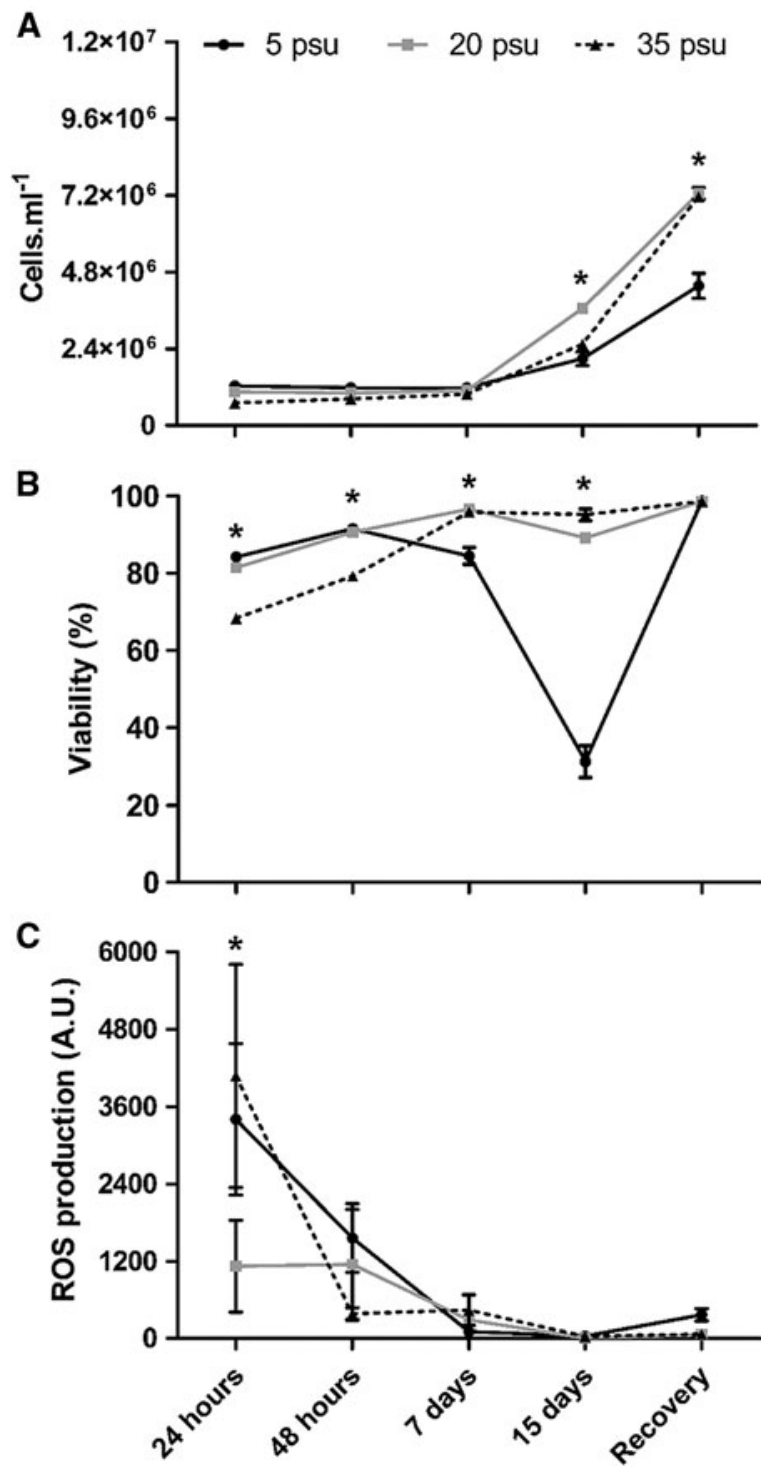

Fig. 3. Cell density (A), cell viability (B) and ROS production (C) of Perkinsus marinus cells maintained at 5, 20 and 35 psu. Values are expressed as mean \pm standard error. Asterisks indicate significant differences between treatments for each time point (post hoc Bonferroni test; $P \leqslant 0 \cdot 01)$.

highest temperature $\left(35^{\circ} \mathrm{C}\right)$ developed Population 2 $(83 \%)$, and those kept at $25^{\circ} \mathrm{C}$ showed Populations $2-4(40 \cdot 8,39 \cdot 3$ and $19 \cdot 9 \%$, respectively). On the 15 th day, Population 2 emerged at the extreme temperatures $\left(15{ }^{\circ} \mathrm{C}: 72 \cdot 4 \% ; 35^{\circ} \mathrm{C}\right.$ : $\left.90 \cdot 3 \%\right)$, together with Population $1\left(15^{\circ} \mathrm{C}: 27 \cdot 6 \%\right.$; $35^{\circ} \mathrm{C}$ : $\left.9 \cdot 7 \%\right)$; whereas control temperature sustained Populations $2-4$, although with different proportions $(8 \cdot 5,83 \cdot 6$ and $7 \cdot 9 \%$, respectively). Recovery period at $25^{\circ} \mathrm{C}$ induced cell changes for all treatments, although in different ways; the cells kept at $15^{\circ} \mathrm{C}$ presented as Populations $1-4$, those kept at $25^{\circ} \mathrm{C}$ presented as Populations 1-3, while at $35^{\circ} \mathrm{C}$ presented as Populations 2-4.

Cell density, viability and ROS production of $P$. marinus cultured under different temperatures are shown in Fig. 5. Perkinsus marinus cell density did not differ among temperatures until the 7 th day (Fig. 5A). After 15 days, the cells maintained at $25{ }^{\circ} \mathrm{C}$ reached a cell density higher $(9 \cdot 3 \pm 0 \cdot 70 \times$ $10^{6}$ cells $\left.\mathrm{mL}^{-1}\right)$ than those of the other treatments $\left(15^{\circ} \mathrm{C}: 1 \cdot 1 \pm 0 \cdot 01 \times 10^{6}\right.$ cells $\mathrm{mL}^{-1}$ and $35^{\circ} \mathrm{C}: 1.53$ $\pm 0.05 \times 10^{6}$ cells $\left.\mathrm{mL}^{-1} ; \quad P<0 \cdot 001\right)$. Recovery at $25^{\circ} \mathrm{C}$ did not modify the density of $P$. marinus cells kept at the highest temperature $\left(35^{\circ} \mathrm{C}: 1 \cdot 7 \pm\right.$ $0 \cdot 05 \times 10^{6}$ cells $\left.\mathrm{mL}^{-1}\right)$, but induced their proliferation at the lowest temperature $\left(15^{\circ} \mathrm{C}: 3 \cdot 3 \pm\right.$ $0 \cdot 10 \times 10^{6}$ cells $\left.\mathrm{mL}^{-1}\right)$. The density of cells kept at $25^{\circ} \mathrm{C}\left(8 \cdot 1 \pm 0 \cdot 50 \times 10^{6}\right.$ cells $\left.\mathrm{mL}^{-1}\right)$ was higher $(P<$ $0 \cdot 001)$ than to those of the other temperatures.

The cell viability of $P$. marinus cultured at $25{ }^{\circ} \mathrm{C}$ was high and constant throughout the experiment (97.4 $\pm 0 \cdot 50 \%$; Fig. 5B), but cells kept at a lower temperature $\left(15^{\circ} \mathrm{C}\right)$ exhibited an abrupt drop in viability after $48 \mathrm{~h}(87 \cdot 1 \pm 0 \cdot 30 \% ; P<0 \cdot 01)$, and further down after the 7 th $(58.3 \pm 1.20 \%, P<0.01)$ and 15 th days $(67 \cdot 5 \pm 0 \cdot 80 \%)(P<0 \cdot 01)$. In contrast, cells kept at $35{ }^{\circ} \mathrm{C}$ showed a slight decrease in viability only on the 15 th day $(91 \cdot 7 \pm 3 \cdot 30 \% ; P<0 \cdot 01)$. In the recovery assay at $25{ }^{\circ} \mathrm{C}$, the viability of cells kept at $15{ }^{\circ} \mathrm{C}(96.9 \pm 2 \cdot 50 \%)$ was equivalent to that of cells kept at $25^{\circ} \mathrm{C}$, whereas those maintained at $35^{\circ} \mathrm{C}$ exhibited a significant reduction in viability $(68 \cdot 3$ $\pm 3.90 \% ; P<0 \cdot 001)$. In all conditions, dead cells were evenly distributed in all populations.

ROS production by $P$. marinus did not differ between the temperatures tested until $48 \mathrm{~h}$ (Fig. 5C). On the 7 th day, cells kept at $35^{\circ} \mathrm{C}$ presented ROS production higher than that of cells kept at $25^{\circ} \mathrm{C}$ $(P<0 \cdot 001)$, and those kept at $15^{\circ} \mathrm{C}$ showed intermediate ROS production. On the 15 th day, cells kept at 15 and $35^{\circ} \mathrm{C}$ presented ROS production values higher than those of cells maintained at $25^{\circ} \mathrm{C}(P<0 \cdot 01)$. In the recovery assay, ROS production was the same for all temperatures.

\section{DISCUSSION}

The identification and in vitro propagation of $P$. marinus occurred for the first time in Brazil in 2013, derived from tissues of C. rhizophorae oysters from the estuary of the Paraíba do Norte River (NE, Brazil; da Silva et al. 2013). Since then, this protozoan parasite and others of the same genus ( $P$. olseni and $P$. beihaiensis) have been identified as parasites of the $C$. gasar oyster (Queiroga et al. 2015; da Silva et al. 2014). However, P. olseni and $P$. beihaiensis have not yet been isolated and cultivated from Brazilian hosts.

Several in vivo (Oliver et al. 1998; Villalba et al. 2005; Gullian-Klanian et al. 2008) and in vitro (Burreson et al. 1994; Burreson and Ragone Calvo, 1996; La Peyre et al. 2006, 2010; Umeda et al. 2013) studies indicate that the protozoa of the genus Perkinsus are, in general, sensitive to extreme 


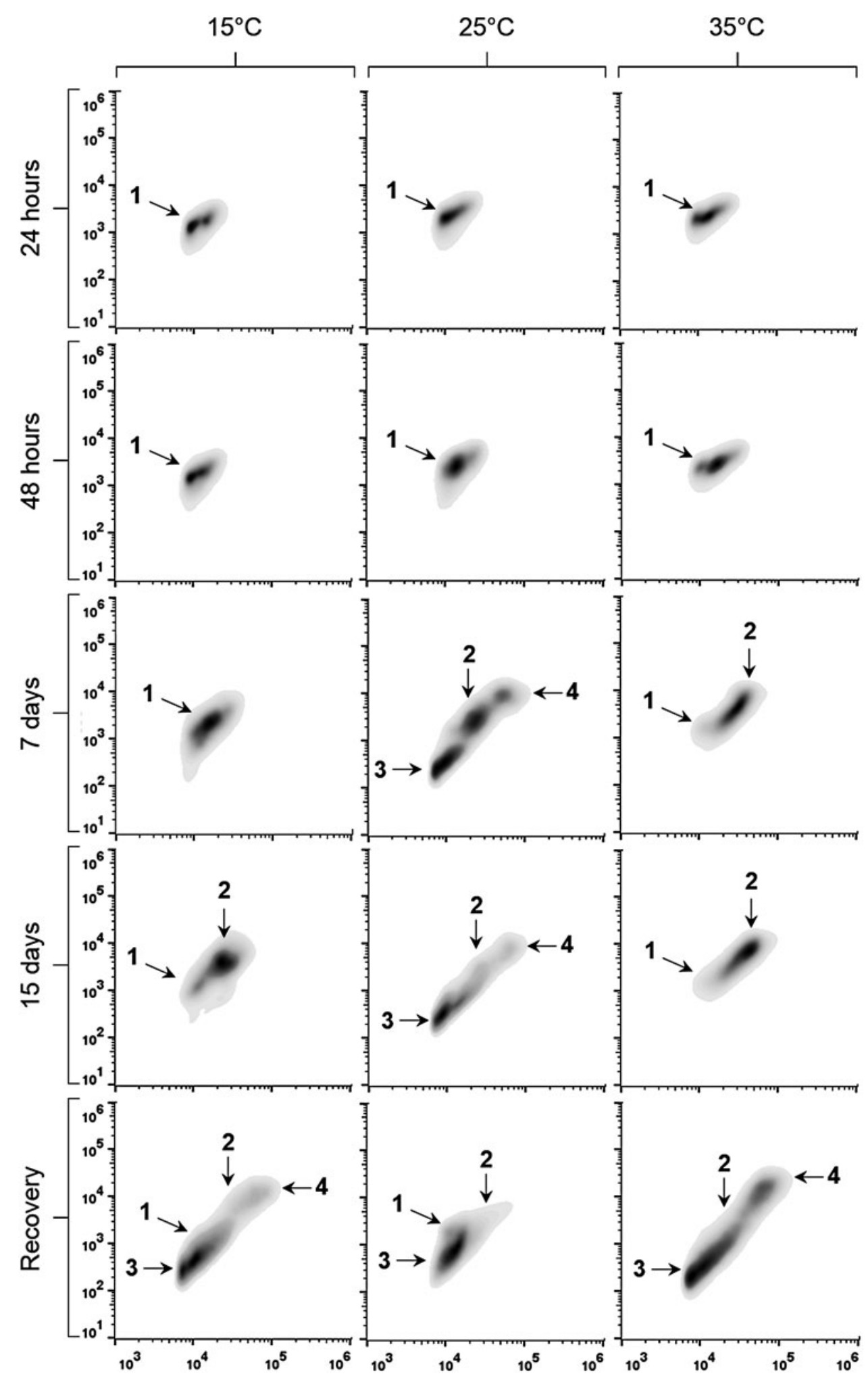

Fig. 4. Density plot of Perkinsus marinus cells maintained at 15,25 and $35^{\circ} \mathrm{C}$ (columns) at different times $(24,48 \mathrm{~h}, 7 \mathrm{days}$, 15 days and in the recovery; rows). The $x$-axis indicates cell size (FSC), and the $y$-axis indicates cell granularity (SSC), both in log scale. Ten thousand events are represented at each cytogram. Numbers $(1,2,3$ and 4$)$ indicate different cell populations.

salinity and temperature conditions. The present study was the first to evaluate the effects of these two abiotic conditions on the physiology of $P$. marinus isolated from a Brazilian native host. The results indicate that the Brazilian P. marinus isolate is also sensitive to extreme temperature and salinity conditions, although in a more pronounced way than others isolates.

In the present study, trophozoites and schizonts, typical Perkinsus cells cultured in vitro (La Peyre 


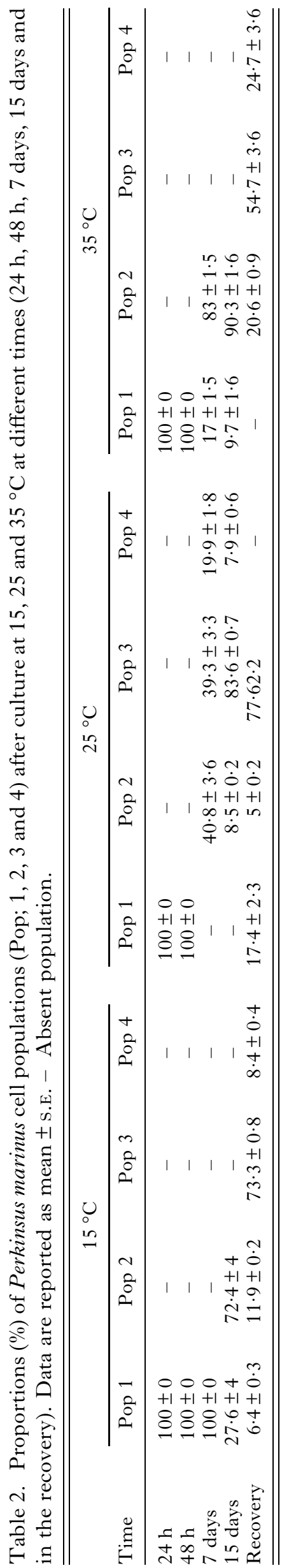

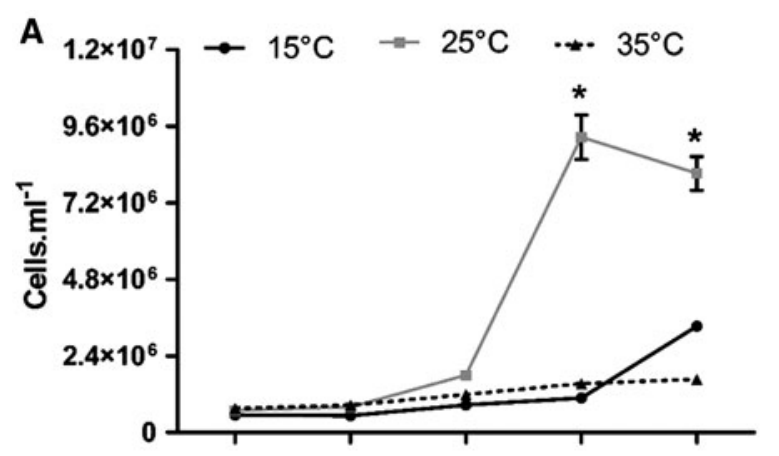

B
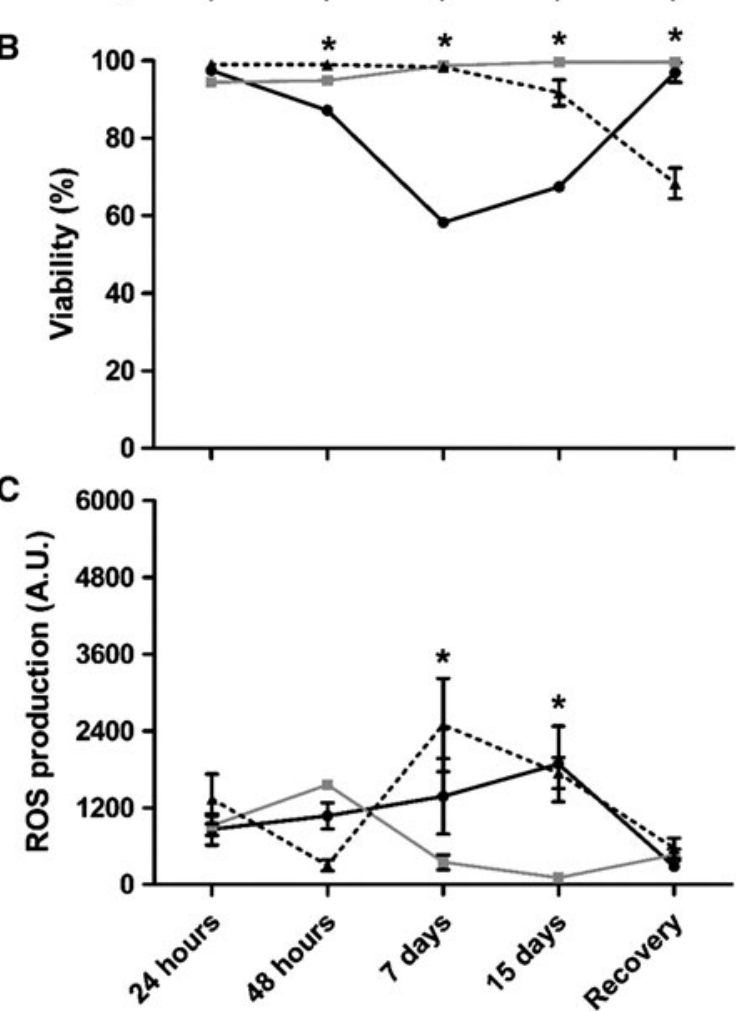

Fig. 5. Cell density (A), cell viability (B) and ROS production (C) of Perkinsus marinus cells maintained at 15 , 25 and $35^{\circ} \mathrm{C}$. Values are expressed as mean \pm standard error. Asterisks indicate significant differences between treatments for each time point (post hoc Bonferroni test; $P \leqslant 0 \cdot 01)$

et al. 1993; Ordás and Figueras, 1998; Sunila et al. 2001; Dang et al. 2015), were observed by microscopy. The development of one cell type into another was inferred from the morphological profile obtained by flow cytometry analysis and confirmed by microscopy. Here, cell density and morphological changes were analysed together by flow cytometry and used successfully to determine the $P$. marinus proliferation.

Among the cell types observed by microscopy, trophozoites showed three distinct morphological patterns (Populations 1-3) when observed on cytograms. Populations 1 and 3 presented cells with the same size (the smallest cells observed), but different granularities. These cell populations may represent different trophozoite developmental phases (La Peyre et al. 1993; Sunila et al. 2001; 
Robledo et al. 2002; Casas et al. 2008). The difference in granularity may be associated with the capacity of $P$. marinus to store lipids in the form of cytoplasmic droplets (Chu et al. 2000, 2003). These lipids can be used for synthesis of structural components, mainly membranes, throughout its growth (Soudant and Chu, 2001; Chu et al. 2000, 2002; Lund et al. 2004). Lipid bodies accumulation also occurs with the intracellular parasite Giardia lamblia in culture (Stevens et al. 1997). Therefore, Population 1 would include older trophozoites than Population 3 because they would have accumulated more granules.

Over time, trophozoites increase in size (Fig. 1B) and undergo successive internal divisions, becoming schizonts (Fig. 1C), which contain immature trophozoites inside (Sunila et al. 2001; Casas et al. 2002; Dang et al. 2015). Large trophozoites and schizonts probably are contained in Population 2 because of their similar size. When the new trophozoites grow, they eventually rupture the schizont's membrane and remain aggregated for some time (Ordás and Figueras, 1998; Sunila et al. 2001), as observed here under the light microscopy analysis, and suggested to be Population 4 (flow cytometry). Therefore, clusters of sibling trophozoites were observed as individual events in the cytograms. Immature trophozoites will be released from the clusters to replenish Population 3. The simultaneous presence of Populations 3 and 4 confirms the hypothesis of the cell cycle described above.

In the assay evaluating the effects of salinity and temperature, control conditions $\left(20\right.$ psu and $\left.25^{\circ} \mathrm{C}\right)$ were the most favourable to $P$. marinus cell development, allowing sustained cell viability, cell phase changes and increase in density. In contrast, only at 5 psu, Population 3 (small trophozoites) emerged on the 7th day, without clusters of sibling trophozoites development. This fact could be explained by an effect of low salinity inducing schizont rupture and the rapid separation of trophozoites from the cluster. Moreover, the subdivision of Population 2 into $2 A$ and $2 B$ could not be simply explained by the high mortality observed in Population 2B (7th day), because cell death causes loss of membrane integrity, thus increasing cell size but not granularity, which as observed here. Instead, this fact corroborates the hypothesis discussed above; i.e. the presence of large trophozoites and schizonts in Population $2(2 A$ and $2 B)$. Nevertheless, low salinity did not interfere with the progress of $P$. marinus cell phase changes, because the composition of cell populations was similar to that at the other salinities (15th and recovery).

The decrease of $P$. marinus proliferation at low salinities, as observed in this study, is a known phenomenon (La Peyre et al. 2006, 2010) associated with perkinsiosis infection dynamics (Oliver et al.
1998; Villalba et al. 2004; Gullian-Klanian et al. 2008; Soniat et al. 2012).

The low density of cells at 35 psu on the 15 th day and the reduction in their viability until $48 \mathrm{~h}$ indicate that high salinity is also deleterious to the development of P. marinus from Brazil. Interestingly, at that time point, at both high and low salinity, the development of proliferative stages (schizonts and clusters of sibling trophozoites) was not affected. It is possible that extreme salinities caused a decrease in the proliferation rate, i.e. schizogony was not totally avoided but occurred at a slower pace and did not result in an increase in cell number.

Unlike salinity, there was no $P$. marinus proliferation at extreme temperatures $\left(15\right.$ and $\left.35^{\circ} \mathrm{C}\right)$ until the 15th day. Other studies have observed that the optimal temperatures for the proliferation of $P$. marinus isolated from the American oyster $C$. virginica were between 15 and $35^{\circ} \mathrm{C}$ (Dungan and Hamilton, 1995; Gauthier and Vasta, 1995). In the case of P. olseni isolated from Ruditapes philippinarum from Japan (Umeda et al. 2013), the optimal temperatures ranged between 20 and $34^{\circ} \mathrm{C}$. However, for an isolate of Ruditapes decussatus from Europe (Ordás and Figueras, 1998), the temperatures were lower (between 16 and $26^{\circ} \mathrm{C}$ ). The low proliferation of $P$. marinus when kept at $35{ }^{\circ} \mathrm{C}$ suggests that this isolate may be more sensitive to high temperatures than those mentioned above, but apparently equally as sensitive as the European P. olseni isolate.

The available studies focusing on in vitro proliferation of Perkinsus spp. contemplate only cell responses of the parasite under a single temperature and salinity condition (Dungan and Hamilton, 1995; Ordás and Figueras, 1998; La Peyre et al. 2006, 2010; Umeda et al. 2013). The present study also evaluated the response of $P$. marinus to its return to control temperature and salinity conditions. In this experiment, we aimed to evaluate the capacity of the parasite to recover from a potential stress situation. These assays could yield results closer to what is observed in the natural environment of oysters where the parasite is subjected to salinity and temperature fluctuations. Such fluctuations are typical of estuarine environments, where the tidal cycle and freshwater supply cause changes in the hydrological conditions.

In the recovery assessment, cells originally maintained at 5 and 35 psu and at $15{ }^{\circ} \mathrm{C}$ showed induction of proliferation accompanied by increased cell viability. These observations suggest that $P$. marinus has a strong capacity to recover after osmotic stress and a low temperature. Interestingly, recovery did not occur in the case of exposure to $35^{\circ} \mathrm{C}$. It is possible that the thermal stress suffered could have caused irreversible damage to the cells, contributing to their death. These observations could also explain why, despite the high prevalence of $P$. marinus 
among oysters in the NE region of Brazil, where high temperatures predominate, no mortality events have been reported to date (farmers, personal communication; da Silva et al. 2013, 2014; Queiroga et al. 2015). In this case, the high temperature in the NE region would be a limiting factor to the proliferation of the parasite.

The amount of ROS in the P. marinus cells was also affected in response to changes in salinity and temperature, although in a different way. This cell parameter has never been studied in protozoa belonging to this genus. What is known is how the parasite avoids the lytic molecules (ROS and RNS) produced and released by the host's defence cells (see review by Soudant et al. 2013).

In marine organisms, responses to increase in seawater temperature activate metabolic processes, resulting in increased ROS levels (Lushchak, 2011). Thus, this would explain the results observed in the present study when parasites were cultured at $35{ }^{\circ} \mathrm{C}$. However, this mechanism does not explain the case of low temperature, which also induced ROS production. Lushchak (2011) speculates that in these rare cases, anti-oxidation mechanisms may be inhibited, although this possibility has not been confirmed. During the recovery period, $P$. marinus ROS values were equivalent to those under control conditions, supporting the direct association of this cell parameter with temperature. In marine animals, intracellular ROS production is also increased in cases of any transient changes (increases or decreases) in salinity. This increase derives from adaptations at the cell level, for example in the activity of proteins involved in energy metabolism and electrolytic balance (Lushchak, 2011). This phenomenon may have occurred in the case of P. marinus cells transitioning from a salinity of 20 psu to 5 or $35 \mathrm{psu}$, but for a short period (24 h).

The sustained elevation of ROS levels in $P$. marinus cells kept at $35{ }^{\circ} \mathrm{C}$ may have contributed to these cells' inability to recover (as indicated by low cell proliferation and viability). Oxidative stress is a condition classically known to generate deleterious effects, such as lipid peroxidation (Mylonas and Kouretas, 1999), protein oxidation (Stadtman and Berlett, 1998) and even DNA oxidation (Cooke et al. 2003; Kelly et al. 2008). Nevertheless, the same does not apply to $P$. marinus cells kept at $15{ }^{\circ} \mathrm{C}$ because these specimens were able to recover even after being exposed to high ROS concentrations. It is probable that ROS do not cause the same effects at low temperatures, which could act as a protector.

In protozoa of the genus Leishmania, an increase in the ROS concentration is directly associated with the parasite's life cycle (Mittra and Andrews, 2013). A transient increase in the $\mathrm{H}_{2} \mathrm{O}_{2}$ concentration occurs before differentiation of the promastigote form into the amastigote form in cell culture. In this context, the ROS levels in P. marinus could also be associated with cell phase changes, since the sustained high ROS levels observed (15 and $35^{\circ} \mathrm{C}$ ) could have promoted the arrest in trophozoite phase (microscopy observation).

In temperate regions, infection by Perkinsus sp. follows temperature variations, and higher infection rates are reported in the warmer seasons and in higher salinity environments (Choi and Park, 2010; Villalba et al. 2011). The data provided in the present study suggest that the $P$. marinus isolated from the estuary of the Paraíba do Norte River is sensitive to both low and high temperatures and salinities. This estuary is located in the tropical region of Brazil, where the temperature varies little and the seasons are defined according to the rainfall (dry and wet seasons); rain in the autumn and winter (May-September) and dry conditions in the spring and summer (October-April). Thus, temperature would have less influence on the dynamics of infection by $P$. marinus in this region, but salinity would have a major role, causing temporal (through rainfall) and spatial (through localization up or down the river in the estuary) changes in perkinsiosis. Field studies in oyster populations in the NE region of Brazil focusing on Perkinsus spp. infection dynamics corroborate this hypothesis, such as low infection in the upper river and in the rainy season (Brandão et al. 2013; da Silva et al. 2014; Queiroga et al. 2015).

Based on the present study's data, we conclude that the P. marinus protozoan isolated from the C. rhizophorae oyster, an oyster native to the NE region of Brazil, presents in vitro higher sensitivity to extreme salinity and temperatures than other P. marinus isolates. Flow cytometry was an effective technique for studying physiological and proliferative (by cell morphological changes and density) aspects of the parasite. Our results will contribute to the understanding the dynamics of perkinsiosis in tropical regions and the impact of the $P$. marinus on hosts, which is of great relevance for predicting or preventing economic and environmental impacts.

\section{ACKNOWLEDGMENTS}

We thank the Laboratório de Farmacologia e Aplicação de Produtos Bioativos (LFAPBIO/IDEP) for allowing the use of the flow cytometer. We thank Dr Robson C. Veras and Dr Fátima L. A. A. Azevedo for their technical assistance.

\section{FINANCIAL SUPPORT}

We thank the Conselho Nacional de Desenvolvimento Cientifico e Tecnológico - CNPq for financial support to the project $\mathrm{CNPq} / \mathrm{MPA}$ No. 406170/2012-6 (to M. P. de S). We sincerely appreciate the scholarship provided for MSc. Fernando R. Queiroga from Coordenação de Aperfeiçoamento de Pessoal de Nivel Superior (CAPES). 
We finally thank the Universidade Federal da Paraíba for financial support to English editing service.

\section{REFERENCES}

Ascenso, R. M. T., Leite, R. B., Afonso, R. and Cancela, M. L. (2009). Expression pattern of Perkinsus olseni genes in response to bivalves with different susceptibility to perkinsosis. Yournal of Fish Diseases 32, 633-636. Brandão, R. P., Boehs, G., Sabry, R. C., Ceuta, L. O., Luz, M. D. S. A., Queiroga, F. R. and da Silva, P. M. (2013). Perkinsus sp. infecting oyster Crassostrea rhizophorae (Guilding, 1828) on the coast of Bahia, Brazil. Fournal of Invertebrate Pathology 112,138-41.

Burreson, E. M. and Ragone Calvo, L. M. (1996). Epizootiology of Perkinsus marinus disease of oysters in Chesapeake Bay, with emphasis on data since 1985. Fournal of Shellfish Research 15, 14-34.

Burreson, E. M., Ragone Calvo, L. M., La Peyre, J. F., Counts, F. and Paynter, K. T. (1994). Acute osmotic tolerance of cultured cells of the oyster pathogen Perkinsus marimus (Apicomplexa:Perkinsida) Comparative Biochemistry and Physiology. Part A, Physiology 109, 575-82. Cáceres-Martínez, J., Ortega, M. G., Vásquez-Yeomans, R., García, T. D. J. P., Stokes, N. A. and Carnegie, R. B. (2012). Natural and cultured populations of the mangrove oyster Saccostrea palmula from Sinaloa, Mexico, infected by Perkinsus marinus. Yournal of Invertebrate Pathology 110, 321-5.

Casas, S. M., La Peyre, J.F., Reece, K. S., Azevedo, C. and Villalba, A. (2002). Continuous in vitro culture of the carpet shell clam Tapes decussatus protozoan parasite Perkinsus atlanticus. Diseases of Aquatic Organisms 52, 217-31.

Casas, S. M., Reece, K. S., Li, Y., Moss, J. a., Villalba, A. and La Peyre, J. F. (2008). Continuous culture of Perkinsus mediterraneus, a parasite of the European flat oyster Ostrea edulis, and characterization of its morphology, propagation, and extracellular proteins in vitro. Fournal of Eukaryotic Microbiology 55, 34-43.

Chen, M., Yang, H., Delaporte, M. and Zhao, S. (2007). Immune condition of Chlamys farreri in response to acute temperature challenge. Aquaculture 271, 479-487.

Choi, K.-S. and Park, K.-I. (2010). Review on the protozoan parasite Perkinsus olseni (Lester and Davis 1981) infection in Asian waters. In Coastal Environmental and Ecosystem Issues of the East China Sea (ed. Ishimatsu, A. and Lie, H. J.), pp. 269-281. TERRAPUB and Nagasaki University, Nagazaki.

Chu, F. E., Soudant, P., Volety, A K. and Huang, Y. (2000). Uptake and interconversion of fluorescent lipid analogs in the protozoan parasite, Perkinsus marinus, of the oyster, Crassostrea virginica. Experimental Parasitology 95, 240-51.

Chu, F.-L.E., Lund, E., Soudant, P. and Harvey, E. (2002). De novo arachidonic acid synthesis in Perkinsus marinus, a protozoan parasite of the Eastern oyster Crassostrea virginica. Molecular and Biochemical Parasitology 119, 179-190.

Chu, F. L. E., Soudant, P. and Lund, E. D. (2003). Perkinsus marinus, a protozoan parasite of the Eastern oyster (Crassostrea virginica): effects of temperature on the uptake and metabolism of fluorescent lipid analogs and lipase activities. Experimental Parasitology 105, 121-130.

Cooke, M. S., Evans, M. D., Dizdaroglu, M. and Lunec, J. (2003). Oxidative DNA damage: mechanisms, mutation, and disease. The FASEB journal: official publication of the Federation of American Societies for Experimental Biology 17, 1195-1214.

da Silva, P. M., Tubino, R. V., Guertler, C., Ferreira, L.P., Santana, L. N., Fernández-boo, S., Ramilo, A., Cao, A. and Villalba, A. (2013). First report of the protozoan parasite Perkinsus marinus in South America, infecting mangrove oysters Crassostrea rhizophorae from the Paraíba River. Fournal of Invertebrate Pathology 113, 96-103.

da Silva, P. M., Scardua, M. P., Vianna, R. T., Mendonca, R. C., Vieira, C. B., Dungan, C. F., Scott, G.P. and Reece, K. S. (2014). Two Perkinsus spp. infect Crassostrea gasar oysters from cultured and wild populations of the Rio São Francisco estuary, Sergipe, northeastern Brazil. Fournal of Invertebrate Pathology 119, 62-71.

Dang, C., Dungan, C., Scott, G. and Reece, K. (2015). Perkinsus sp. infections and in vitro isolates from Anadara trapezia (mud arks) of Queensland, Australia. Diseases of Aquatic Organisms 113, 51-58. Dungan, C. F. and Hamilton, R. M. (1995). Use of a tetrazolium-based cell proliferation assay to measure effects of in vitro conditions on Perkinsus marinus (Apicomplexa) proliferation. The Fournal of Eukaryotic Microbiology 42, 379-388.

Dungan, C.F., Reece, K.S., Moss, J. a., Hamilton, R.M. and Diggles, B. K. (2007). Perkinsus olseni in vitro isolates from the New
Zealand clam Austrovenus stutchburyi. The Fournal of Eukaryotic Microbiology 54, 263-70.

Gauthier, J. D. and Vasta, G. R. (1993). Continuous in vitro culture of the eastern oyster parasite Perkinus marinus. Fournal Invertebrate Pathology 62, 321-323.

Gauthier, J. D. and Vasta, G. R. (1995). In vitro culture of the Eastern oyster parasite Perkinsus marimus: optimization of the methodology. Fournal of Invertebrate Pathology 66, 156-168.

Gullian-Klanian, M., Herrera-Silveira, J. A., Rodríguez-Canul, R. and Aguirre-Macedo, L. (2008). Factors associated with the prevalence of Perkinsus marinus in Crassostrea virginica from the southern Gulf of Mexico. Diseases of Aquatic Organisms 79, 237-47.

Hégaret, H., Wikfors, G. H. and Soudant, P. (2003). Flow cytometric analysis of haemocytes from Eastern oysters, Crassostrea virginica, subjected to a sudden temperature elevation. Fournal of Experimental Marine Biology and Ecology 293, 249-265.

Kelly, M. C., White, B. and Smyth, M. R. (2008). Separation of oxidatively damaged DNA nucleobases and nucleosides on packed and monolith C18 columns by HPLC-UV-EC. Fournal of Chromatography B: Analytical Technologies in the Biomedical and Life Sciences 863, 181-186.

La Peyre, J. F., Faisal, M. and Burreson, E. M. (1993). In vitro propagation of the protozoan Perkinsus marinus, a pathogen of the Eastern oyster, Crassostrea virginica. The Gournal of Eukaryotic Microbiology 40 304-301.

La Peyre, M., Casas, S. and La Peyre, J. (2006). Salinity effects on viability, metabolic activity and proliferation of three Perkinsus species. Diseases of Aquatic Organisms 71, 59-74.

La Peyre, M. K., Casas, S. M., Gayle, W. and La Peyre, J. F. (2010). The combined influence of sub-optimal temperature and salinity on the in vitro viability of Perkinsus marinus, a protistan parasite of the Eastern oyster Crassostrea virginica. Fournal of Invertebrate Pathology 105, 176-81. Lambert, C., Soudant, P., Choquet, G. and Paillard, C. (2003). Measurement of Crassostrea gigas hemocyte oxidative metabolism by flow cytometry and the inhibiting capacity of pathogenic vibrios. Fish $\sigma^{\circ}$ Shellfish Immunology 15, 225-240.

Lund, E. D., Chu, F.-L. E. and Harvey, E. (2004). In vitro effects of temperature and salinity on fatty acid synthesis in the oyster protozoan parasite Perkinsus marinus. Fournal of Experimental Marine Biology and Ecology 307, $111-126$.

Lund, E. D., Chu, F.-L. E., Soudant, P. and Harvey, E. (2007). Perkinsus marinus, a protozoan parasite of the Eastern oyster, has a requirement for dietary sterols. Comparative Biochemistry and Physiology. Part A, Molecular and Integrative Physiology 146, 141-7.

Lushchak, V. I. (2011). Environmentally induced oxidative stress in aquatic animals. Aquatic Toxicology 101,13-30.

Mclaughlin, S. M. and Faisal, M. (1998). In vitro propagation of two Perkinsus species from the softshell clam Mya arenaria. Parasite 5, 341-348.

Mittra, B. and Andrews, N. W. (2013). IRONy OF FATE: role of ironmediated ROS in Leishmania differentiation. Trends in Parasitology 29, 489-496.

Mylonas, C. and Kouretas, D. (1999). Lipid peroxidation and tissue damage. In Vivo 13, 295-309.

OIE (2015). World Organisation for Animal Health. OIE-Listed diseases, infections and infestations. http://www.oie.int/animal-health-in-theworld/oie-listed-diseases-2015/

Oliver, L. M., Fisher, W. S., Ford, S. E., Calvo, L. M., Burreson, E. M., Sutton, E. B. and Gandy, J. (1998). Perkinsus marinus tissue distribution and seasonal variation in oysters Crassostrea virginica from Florida, Virginia and New York. Diseases of Aquatic Organisms 34, 51-61.

Ordás, M. C. and Figueras, A. (1998). In vitro culture of Perkinsus atlanticus, a parasite of the carpet shell clam Ruditapes decussatus. Diseases of Aquatic Organisms 33, 129-136.

Queiroga, F.R., Golzio, J.E., Santos, R.B., Martins, T.O. and Vendel, A.L. (2012). Reproductive biology of Sciades herzbergii (Siluriformes: Ariidae) in a tropical estuary in Brazil. Zoologia 29, 397-404. Queiroga, F. R., Marques-Santos, L. F., Hégaret, H., Soudant, P., Farias, N. D., Schlindwein, A. D. and da Silva, P. M. (2013). Immunological responses of the mangrove oysters Crassostrea gasar naturally infected by Perkinsus sp. in the Mamanguape Estuary, Paraíba state (Northeastern, Brazil). Fish and Shellfish Immunology 35, 319-327. Queiroga, F. R., Vianna, R. T., Vieira, C. B., Farias, N.D. and da Silva, P. M. (2015). Parasites infecting the cultured oyster Crassostrea gasar (Adanson, 1757) in Northeast Brazil. Parasitology 142, 756-766. Robledo, J. A., Nunes, P. A., Cancela, M. L. and Vasta, G. R. (2002). Development of an in vitro clonal culture and characterization of the rRNA gene cluster of Perkinsus atlanticus, a protistan parasite of the clam Tapes decussatus. The Yournal of Eukaryotic Microbiology 49, 414-422. 
Sauer, H., Wartenberg, M. and Hescheler, J. (2001). Reactive oxygen species as intracellular messengers during cell growth and differentiation. Cellular Physiology and Biochemistry 11, 173-186.

Smolowitz, R. (2013). A review of current state of knowledge concerning Perkinsus marinus effects on Crassostrea virginica (Gmelin) (the eastern oyster). Veterinary Pathology 50, 404-11.

Soniat, T. M., Klinck, J. M., Powell, E. N. and Hofmann, E. E. (2012). Understanding the success and failure of oyster populations: periodicities of Perkinsus marinus, and oyster recruitment, mortality, and size. Fournal of Shellfish Research 31, 635-646.

Soudant, P. and Chu, F. L. (2001). Lipid class and fatty acid composition of the protozoan parasite of oysters, Perkinsus marinus cultivated in two different media. The Fournal of Eukaryotic Microbiology 48, 309-319.

Soudant, P., Chu, F. L. E. and Lund, E. D. (2005). Assessment of the cell viability of cultured Perkinsus marinus (Perkinsea), a parasitic protozoan of the Eastern oyster, Crassostrea virginica, using SYBRgreen-propidium iodide double staining and flow cytometry. The Fournal of Eukaryotic Microbiology 52, 492-499.

Soudant, P., E Chu, F.-L. and Volety, A. (2013). Host-parasite interactions: marine bivalve molluscs and protozoan parasites, Perkinsus species. Fournal of Invertebrate Pathology 114, 196-216.

Stadtman, E. R. and Berlett, B.S. (1998). Reactive oxygen-mediated protein oxidation in aging and disease. Drug Metabolism Reviews 30, 225-43. Stevens, T. L., Gibson, G. R., Adam, R., Maier, J., Allison-Ennis, M. and Das, S. (1997). Uptake and cellular localization of exogenous lipids by Giardia lamblia, a primitive eukaryote. Experimental Parasitology 86, 133-143.
Sunila, I., Hamilton, R. M. and Dungan, C. F. (2001). Ultrastructural characteristics of the in vitro cell cycle of the protozoan pathogen of oysters, Perkinsus marinus. The Fournal of Eukaryotic Microbiology 48, 348-61.

Umeda, K., Shimokawa, J. and Yoshinaga, T. (2013). Effects of temperature and salinity on the in vitro proliferation of trophozoites and the development of zoosporangia in Perkinsus olseni and P. honshuensis, both infecting manila clam. Fish Pathology 48, 13-16.

Villalba, A., Reece, K.S., Camino Ordás, M., Casas, S.M. and Figueras, A. (2004). Perkinsosis in molluscs: a review. Aquatic Living Resources 17, 411-432.

Villalba, A., Casas, S. M., López, C. and Carballal, M. J. (2005). Study of perkinsosis in the carpet shell clam Tapes decussatus in Galicia (NW Spain). II. Temporal pattern of disease dynamics and association with clam mortality. Diseases of Aquatic Organisms 65, 257-67.

Villalba, A., Gestal, C., Casas, S. M. and Figueras, A. (2011). Perkinsosis en moluscos. In Enfermedades de moluscos bilvalvos de interés en acuicultura (ed. Figueras, A. and Novoa, B.), pp. 181-424. Fundación Observatorio Español de Acuicultura, Madrid.

Wardman, P. (2007). Fluorescent and luminescent probes for measurement of oxidative and nitrosative species in cells and tissues: progress, pitfalls, and prospects. Free Radical Biology and Medicine 43, 995-1022.

Zhang, M., Shi, J. and Jiang, L. (2015). Modulation of mitochondrial membrane integrity and ROS formation by high temperature in Saccharomyces cerevisiae. Electronic Fournal of Biotechnology 18, 202-209. 